\title{
Impact of Burning Pinyon-Juniper Debris on Select Soil Properties
}

\author{
GERALD F. GIFFORD
}

\section{Abstract}

Burning had the greatest impact on soils beneath burned debris piles. Electrical conductivity, phosphorus, potassium, percent nitrogen, and percent organic carbon increased significantly at all soil depths the first year after burning debris piles. No impact was evident on phosphorus, percent nitrogen, and percent organic carbon by the second year. Impacts on burned interspace areas were generally less pronounced and few impacts were measured the second year. Impact of burning on soil pH was minor.

Burning as a management tool is becoming increasingly important within the pinyon-juniper (Pinus spp.-Juniperus spp.) type. Wright et al. (1979) have recently reviewed the role and use of fire in pinyon-juniper plant communities. Wells et al. (1979) have indicated that under rangeland conditions, effects of fire on organisms and soil are highly variable. From the soils standpoint, fire may significantly affect available nutrient supplies, at least initially. The amount of nutrients released either in the form of volatiles or ash depends on the quantity available in the aboveground vegetation consumed by the fire. Studies within various vegetation types seem to indicate that the nitrogen status of soils following fire varies greatly while burning does not appreciably reduce the amount of phosphorus, potassium, calcium, magnesium, and various micronutrients (Mueggler 1976). Wells et al. (1979) indicate that conflicting changes in chemical properties of range soils (particularly nitrogen content and phosphorus and potassium levels) appear to result from widely varying fuel cha racteristics and loading and fire intensity. Buckhouse and Gifford (1976b) found significant increase in potassium and phosphorus in overland flow following a control burn on a pinyon-juniper debrisin-place site in southeastern Utah. No significant treatment changes were detected for sodium, calcium, or nitrate-nitrogen.

The objective of this study was to determine the impact of burning pinyon-juniper debris on a site in southeastern Utah on $\mathrm{pH}$, conductivity, phosphorus, potassium, percent nitrogen, and percent organic carbon of $2.5 \mathrm{~cm}$ incremental soil surface depths to a total depth of $10 \mathrm{~cm}$.

\section{Site Description and Methods}

The study site is located near Coyote Flat, approximately $1 \mathrm{~km}$ west of Utah Highway 621, between Natural Bridges National Monument and Mexican Hat, Utah, and approximately $70 \mathrm{~km}$ west of Blanding, Utah. The study area is located at an elevation of $2,150 \mathrm{~m}$ and is within the confines of the Colorado Plateau.

Soils at the study site a re wind derived (Aridic Arguistolls-Typic Argiustolls association) from a sandstone parent material, and may extend to a depth of approximately $1.5 \mathrm{~m}$. The $\mathrm{pH}$ of the soil is slightly basic, averaging about 8.0. Organic matter content is low,

\footnotetext{
Author is professor and chairman, Watershed Science Unit, College of Natural Resources, Utah State University, Logan, 84322.

This st udy was part of a cooperative project between the Utah Agricultural Experiment Station (Project 749) and the Bureau of Land Management. Technical Paper Number 2477, Utah Agricultural Experiment Station, Utah State University, Logan, 84322.

Manuscript received November 19, 1979.
}

slightly less than $2.0 \%$. Soil texture is a sandy loam, with few rocks present.

The pinyon and juniper trees were double-chained with debrisin-place in 1967. The site (about 14 ha) was then broadcast seeded at $9.1 \mathrm{~kg} / \mathrm{ha}$ to crested wheatgrass (Agropyron cristatum) and fenced to exclude livestock.

The area was burned on September 5, 1974. At the time of the burn air temperature was $29^{\circ} \mathrm{C}$, relative humidity was 10 to $12 \%$, and the wind was somewhat variable at 17 to $25 \mathrm{~km} / \mathrm{hr}$. The crested wheatgrass fuel load (current year's growth plus accumulated litter) was about $845 \mathrm{~kg} / \mathrm{ha}$.

Temperature extremes within debris piles and in the interspace areas were determined using Tempils with a melt range from $52^{\circ} \mathrm{C}$ to $927^{\circ} \mathrm{C}$. Forty-six replicated measurements were taken at a 2.5 $\mathrm{cm}$ soil depth and at a height of $10 \mathrm{~cm}$ above the soil surface. Table 1 shows mcan temperatures encountered during the burn.

Table 1. Mean temperatures, debris-in-place controlled burn (as defined by the use of Tempils with defined melting points from $52^{\circ} \mathrm{C}$ to $927^{\circ} \mathrm{C}$ ).

\begin{tabular}{lcc}
\hline \hline & $\begin{array}{c}\text { Open, grassy } \\
\text { interspace area }\end{array}$ & Debris pile \\
\hline $10 \mathrm{~cm}$ above soil surface & $187^{\circ} \mathrm{C}$ & $>777^{\circ} \mathrm{C}$ \\
$2.5 \mathrm{~cm}$ soil depth & $<55^{\circ} \mathrm{C}$ & $288^{\circ} \mathrm{C}$ \\
\hline
\end{tabular}

Total energy expended at 46 locations within the burned area was determined using water-can fire analogs as described by George (1969). These analogs were gallon and quart unused paint cans that were painted a flat black, filled with a known weight of water, and placed at ground level. Holes about $1.5 \mathrm{~cm}$ in diameter were punched in the cans immediately prior to the burn and then the holes were taped shut following the burn. Energy expended at each sampling point was simply approximated by determining the weight of water lost from the cans in grams and multiplying by 540 calories, the latent heat of vaporization of water at $100^{\circ} \mathrm{C}$. Since water temperature in the cans at the time of the fire was approximately $27^{\circ} \mathrm{C}$, the energy calculations are obviously on the conservative side (Table 2).

Table 2. Approximate energy release at various sampling points on burned debris-in-place site.

Sampling position

Interspace (grassy) area

Live juniper tree ( $1.4 \mathrm{~m}$ tall)

Debris pile (1 tree)

Debris pile (2 trees)

Debris pile ( 3 trees)

Edge of debris pile ( 3 trees)

Debris pile (4 trees)

Debris pile $(>6$ trees)

Ephedra shrub
Approximate energy release (calories $\times 10^{3}$ )

10.2 to 65.9

120.4 to $1,064.3$

305.6 to $1,403.5$

$1,059.5$ to $>1,591.4$

$1,070.3$ to $>1,601.6$

37.5 to 515.7

661.5 to $>1,600.0$

$1,126.9$ to $>1,598.4$

14.6 to 167.4 
Soil samples were collected in early June of 1975 and 1976 from burned interspaces (grass only) areas, where debris piles had burned, and from adjacent unburned debris-in-place area (identical treatment, but not burned). Thirty randomized samples were taken from each treatment at depths of $0-2.5 \mathrm{~cm}, 2.5-5 \mathrm{~cm}, 5-7.5$ $\mathrm{cm}$, and $7.5-10.0 \mathrm{~cm}$. In each instance the 30 samples were then lumped and six samples were taken for standard laboratory analysis of $\mathrm{pH}$, elect rical conductivity, phosphorus, potassium, nitrogen $(\%)$, and organic carbon $(\%)$.

\section{Results and Discussion}

\section{pH}

There was a general tendency for soil $\mathrm{pH}$ values to be significantly higher in 1975 than in 1976 for a specific treatment at a given soil depth. Differences among treatments within either year were less consistent. Overall the differences may be regarded as rather minor since the range in $\mathrm{pH}$ among treatments at any given soil depth was generally no more than 0.3 to 0.4 units.

\section{Electrical Conductivity}

As may be seen in Figure 1, burning caused a dramatic increase in electrical conductivity at all depths in soils beneath burned debris piles. The increase was still very evident during 1976. Differences between the unburned site and burned interspace areas are relatively minor. Despite the increase in electrical conductivity of soils under burned debris piles, the quantity of soluble salts present represents no problem with respect to plant growth or water quality.

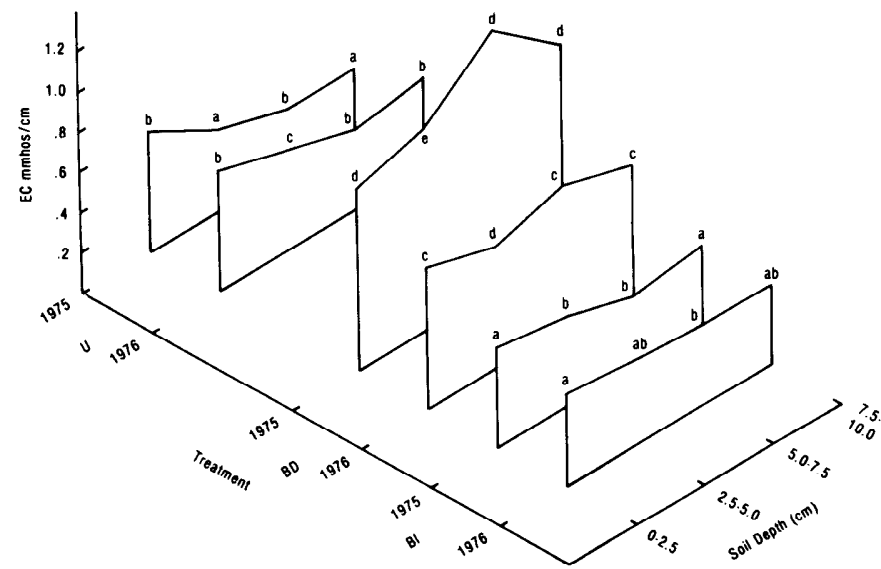

Fig. 1. Electrical conductivity values at four soil depths on three treatments during 1975 and 1976. $U$ indicates unburned, BD indicates burned debris-piles, and BI indicates burned interspaces. Any two means within a specific soil depth with the same letter are not significantly different $(\mathrm{P}<.05)$.

\section{Phosphorus}

Figure 2 indicates a significant increase in phosphorus at nearly all soil depths in 1975 on both burned interspace and burned debris sites. The increase had disappeared, however, by June, 1976.

\section{Potassium}

Significant increases in potassium were noted for all soil depths in 1975 on both burned interspace and burned debris sites (Fig. 3). The increases were still evident in 1976 to a depth of $5 \mathrm{~cm}$ on the burned interspace sites and to a depth of $7.5 \mathrm{~cm}$ on the burned debris sites. As with the phosphorus, the greatest impact was in 1975 in soils under burned debris piles. Differences in 1976 were less pronounced.

\section{Percent Nitrogen}

Percent nitrogen increased slightly (though significantly) in 1975 at nearly all soil depths on burned debris sites (Figure 4). This

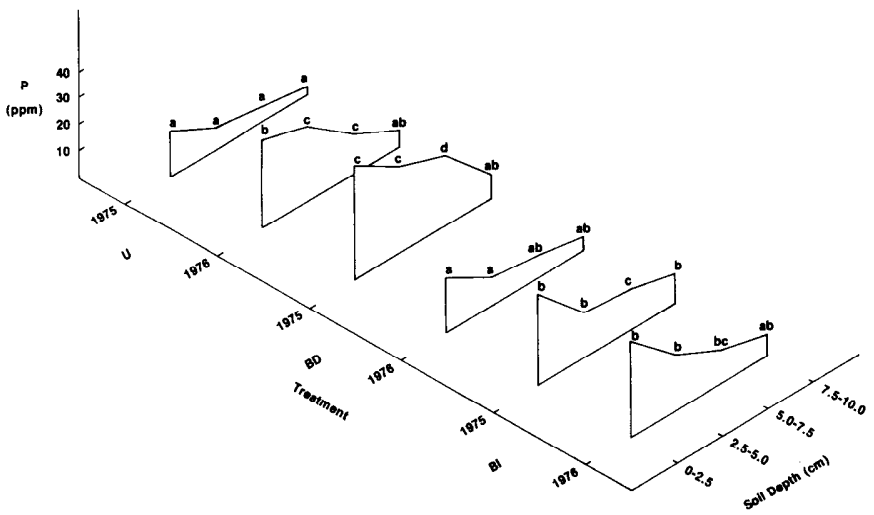

Fig. 2. Phosphorus values at four soil depths on three treatments during 1975 and 1976. U indicates unburned, BD indicates burned debris-piles, and BI indicates burned interspaces. Any two means within a specific soil depth with the same letter are not significantly different $(\mathrm{P}<.05)$.

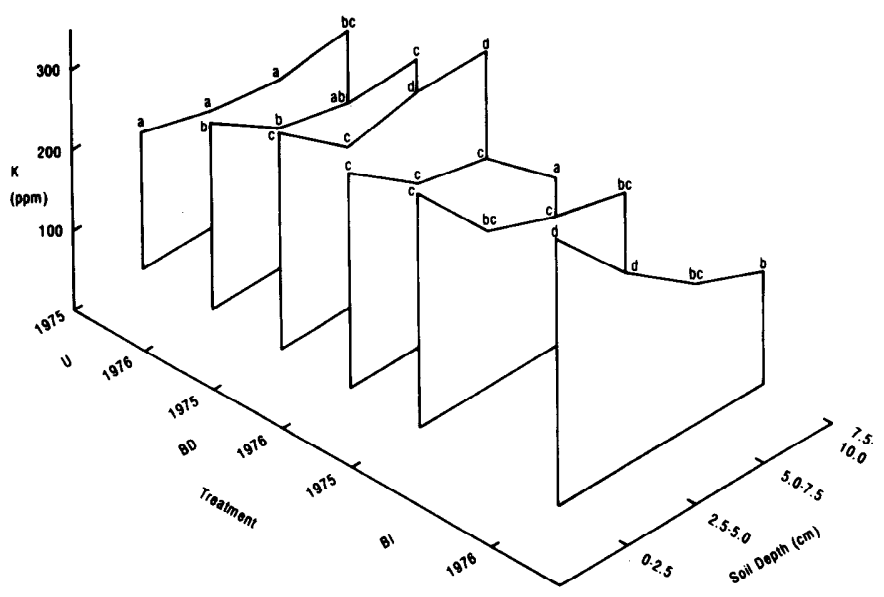

Fig. 3. Potassium values at four soil depths on three treatments during 1975 and 1976. U indicates unburned, BD indicates burned debris-piles, and BI indicates burned interspaces. Any two means within a specific soil depth with the same letter are not significantly different $(\mathrm{P}<.05)$.

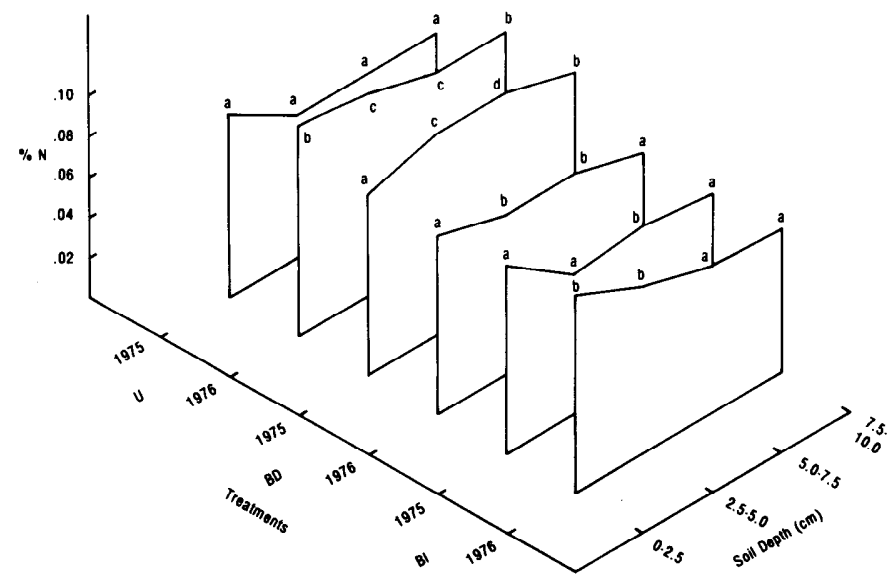

Fig. 4. Percent nitrogen values at four soil depths on three treatments during 1975 and 1976. $U$ indicates unburned, BD indicates burned debris-piles, and BI indicates burned interspaces. Any two means within a specific soil depth with the same letter are not significantly different $(\mathrm{P}<.05)$. 
increase had disappeared by June of 1976. Nitrogen showed little or no response to burning at any soil depth on the interspace area.

\section{Percent Organic Carbon}

As shown in Figure 5, organic carbon significantly increased at $2.5-5.0 \mathrm{~cm}, 5.0-7.5 \mathrm{~cm}$, and $7.5-10.0 \mathrm{~cm}$ soil depths on burned debris sites in 1975. There was a small (though significant) reduction in organic carbon at the $0-2.5 \mathrm{~cm}$ soil depth. These differences disappeared by 1976 , and little or no impacts were found on the burned interspace area.

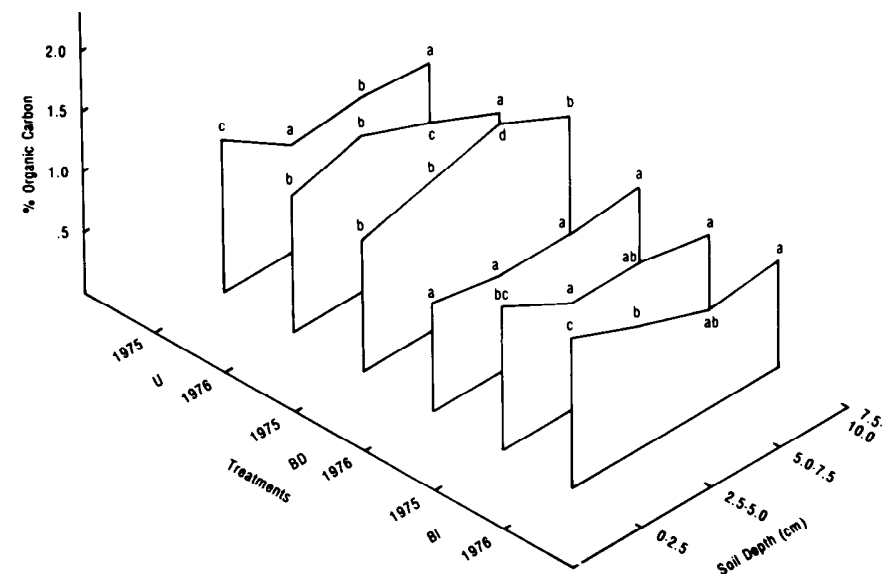

Fig. 5. Percent organic carbon values at four soil depths on three treatments during 1975 and 1976. U indicates unburned, BD indicates burned debris-piles, and BI indicates burned interspaces. Any two means within a specific soil depth with the same letter are not significant different $(\mathrm{P}<.05)$.

\section{Conclusions}

As previously indicated, the impact of fire on soil properties is a function of fuel characteristics and loading and fire intensity. Where pinyon and juniper debris are concerned, a mosaic of impacts might be envisioned since a portion of the area is covered with relatively light fuels which burn rather quickly while the remaining portion is covered with trees, which burn slower and hotter. It was the objective of the study to examine select nutrient and related aspects within the upper $10 \mathrm{~cm}$ of soil profile that might be impacted by the burning of pinyon-juniper debris.

The greatest impact of burning was found in soils that were beneath burned debris piles. Significant first year (1975) increases in clectrical conductivity, phosphorus, potassium, percent nitrogen, and percent organic carbon were found at most soil depths in the burned debris pile area. By 1976 there was little or no impact on phosphorus, percent nitrogen, and percent organic cabon. Impacts were generally less on burned interspace areas and few impacts were observed by the second year. Impact of burning on soil $\mathrm{pH}$ was minor.

The overall ecological importance of the above changes in soil chemical properties is probably relatively minor. Excessive heat generated by burning debris piles and species physiological response to burning represent probable major concerns. Wright et al. (1979) provides a summary of fire effects on major grasses, forbs, and shrubs within the pinyon-juniper sites type, but they fail even to mention the impact of soil chemical change. Changes may occur on pinyon-juniper sites following burning due to increased runoff and erosion (Buckhouse and Gifford 1976b), but these changes are apparently only temporary (Wright et al. 1976, Roundy et al. 1978). From a watershed standpoint, pinyon and juniper debris should not be burned, at least in the Intermountain region (Gifford 1973). Where watershed conditions are of minor importance, then burning appears to be a feasible management option that represents minimal environmental disturbance.

\section{Literature Cited}

Buckhouse, J.C., and G.F. Gifford. 1976a. Grazing and debris burning on pinyon-juniper sites-some chemical water quality implications. J. Range Manage. 29:299-301.

Buckhouse, J.C., and G.F. Gifford. 1976b. Sediment production and infiltration rates as affected by grazing and debris burning on chained and seeded pinyon-juniper. J. Range Manage. 29:83-85.

George, C.W. 1969. A water-can fire analog-its thermal characteristics and calibration. M.S. Thesis, Univ. of Montana.

Gifford, G.F. 1973. Runoff and sediment yields from runoff plots on chained pinyon-juniper sites in Utah. J. Range Manage. 26:440-443.

Mueggler, W.F. 1976. Ecological role of fire in western woodland and range ecosystems. In: Use of Prescribed Burning in Western Woodland and Range Ecosystems, a Symposium, March, Utah State Univ., Logan: $1-9$.

Roundy, B.A., W.H. Blackburn, and R.E. Eckert, Jr. 1978. Influence of prescribed burning on infiltration and sediment production in the pinyon-juniper woodland, Nevada. J. Range Manage. 31:250-253.

Wells, C.G., R.E. Campbell, L.F. DeBano, C.E. Lewis, R.L. Fredriksen, E.C. Franklin, R.C. Froelich, and P.E. Dunn. 1979. Effects of fire on soil. A state-of-knowledge review. U.S. Forest Serv. General Tech. Rep. WO-7: $34 \mathrm{p}$.

Wright, H.A., F.M. Churchill, and W.C. Stevens. 1976. Effect of prescribed burning on sediment, water yield, and water quality from dozed juniper lands in central Texas. J. Range Manage. 29:294-298.

Wright, H.A., L.F. Neuenschwander, and C.M. Britton. 1979. The role and use of fire in sagebrush-grass and pinyon-juniper plant communities. U.S. Forest Serv. Gen. Tech. Rep. INT-58: 48 p. 